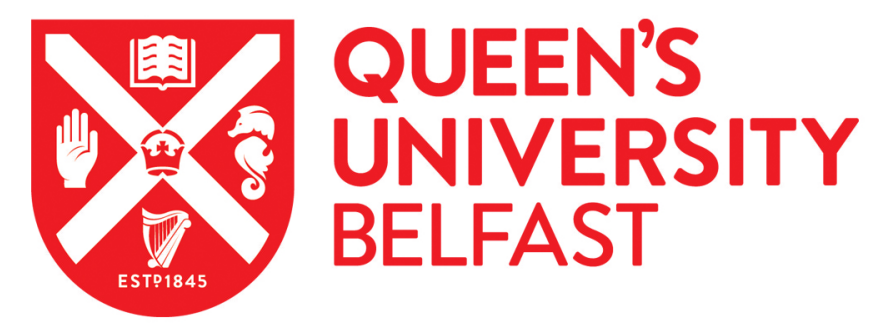

\title{
Linking Core Self-Evaluation to Creativity: The Roles of Knowledge Sharing and Work Meaningfulness
}

Zhang, Y., Sun, J., Lin, C., \& Ren, H. (2018). Linking Core Self-Evaluation to Creativity: The Roles of Knowledge Sharing and Work Meaningfulness. Journal of business and psychology. https://doi.org/10.1007/s10869-0189609-y

Published in:

Journal of business and psychology

Document Version:

Peer reviewed version

Queen's University Belfast - Research Portal:

Link to publication record in Queen's University Belfast Research Portal

Publisher rights

(C) 2018 Springer Science+Business Media New York

This work is made available online in accordance with the publisher's policies. Please refer to any applicable terms of use of the publisher.

\section{General rights}

Copyright for the publications made accessible via the Queen's University Belfast Research Portal is retained by the author(s) and / or other copyright owners and it is a condition of accessing these publications that users recognise and abide by the legal requirements associated with these rights.

Take down policy

The Research Portal is Queen's institutional repository that provides access to Queen's research output. Every effort has been made to ensure that content in the Research Portal does not infringe any person's rights, or applicable UK laws. If you discover content in the Research Portal that you believe breaches copyright or violates any law, please contact openaccess@qub.ac.uk. 
RUNNING HEAD: CSE AND CREATIVITY

Linking Core Self-Evaluation to Creativity: The Roles of Knowledge Sharing and Work Meaningfulness

\begin{abstract}
Whereas core self-evaluation (CSE) has been proposed as an antecedent of creativity, surprisingly, little research has examined it. Extending prior research on CSE, this study investigates when and how CSE relates to creativity. Drawing on the approach/avoidance theoretical framework (Elliot \& Thrash, 2002), we propose that employee's knowledge sharing behavior serves as a mechanism that links CSE to creativity. We further examine the positive moderating effect of work meaningfulness as an activator of the approach tendencies of high-CSE employees. We tested our hypotheses using two-wave multi-source data from a sample of 200 researchers and their supervisors. The results fully supported our hypotheses, and offered both theoretical implications and practical implications.
\end{abstract}

Keywords:

Core self-evaluation; Creativity; Approach/avoidance framework; Work meaningfulness; Knowledge sharing 


\section{RUNNING HEAD: CSE AND CREATIVITY}

Core self-evaluation (CSE) is a broad personality trait that represents an individual's fundamental evaluations of their own ability, competence, and values (Judge, Erez, \& Bono, 1998; Judge, Locke, \& Durham, 1997). It is a higher-order multidimensional construct consisting of four interrelated components: self-esteem, generalized self-efficacy, locus of control, and emotional stability (Johnson, Rosen, \& Chang, 2011; Judge, Bono, \& Locke, 2000). Studies have documented that CSE represents a positive self-concept and is associated with a wide range of positive work behaviors, such as task performance (e.g., Erez \& Judge, 2001), organizational citizenship behavior (OCB; e.g., Rich, LePine, \& Crawford, 2010), transformational leadership behaviors (e.g., Hu, Wang, Liden, \& Sun, 2012), and voice behavior (e.g., Aryee, Walumbwa, Mondejar, \& Chu, 2017).

Despite recent calls for CSE research to further expand the performance criteria space (Judge \& Kammeyer-Mueller, 2011; Chang, Ferris, Johnson, Rosen, \& Tan, 2012) to include constructs "that have become important in light of the dynamic environment in which organizations operate" (Aryee et al., 2017, p. 948), it is surprising that, with just a few exceptions (Chiang, Hsu, \& Hung, 2014; Zhang, Kwan, Zhang, \& Wu, 2014), little research has been conducted thus far to investigate the effect of CSE on creativity. Creativity is the generation of novel and useful ideas concerning products, services, and work methods (Amabile, 1988). In today's dynamic environment, organizations are increasingly reliant on employee creativity and innovation to sustain success and long-term survival (Anderson, De Dreu, \& Nijstad, 2004; Anderson, Potočnik, \& Zhou, 2014). Noting this, it is thus important to extend CSE research to examine its effect on creativity.

Researchers have proposed CSE to be a possible antecedent of creativity (Judge \& Kammeyer-Mueller, 2011). Indeed, there are good reasons to believe that there is a positive association between both constructs. Creativity-related activities are inherently uncertain, as they are not guaranteed to deliver desired outcomes (Zhou \& George, 2001). Despite the 


\section{RUNNING HEAD: CSE AND CREATIVITY}

desirability of creativity, people are biased against it out of the motivation to reduce uncertainty (Ederer \& Manso, 2013; Mueller, Melwani, \& Goncalo, 2012). Hence, a strong tendency to take risks and pursue conceivable positive outcomes is imperative for creativity (Dewett, 2006). The approach/avoidance framework (Elliot \& Thrash, 2002) asserts that CSE represents a strong approach temperament and a weak avoidance temperament (Chang et al., 2012; Ferris et al., 2011), that is, individuals with higher CSE are more sensitive to positive stimuli and insensitive to negative stimuli (or, individuals with lower CSE are more sensitive to negative stimuli and insensitive to positive stimuli). High-CSE individuals, therefore, may be "wired" to see more positive aspects of creativity-related activities. As they are also more confident in attaining positive outcomes (Judge et al., 1998; Judge \& Kammeyer-Mueller, 2011), they are more likely to engage in behaviors that are conducive to creativity. One recent study (Chiang et al., 2014) found that workers high on CSE engaged in more behaviors that acquired job-related knowledge and were more intrinsically motivated, which positively related to higher creativity. This study provides initial empirical evidence of a positive association between CSE and creativity. Nonetheless, on a whole, empirical research on this relationship is still scarce.

Moreover, we know little about what behavior engendered by high CSE could lead to an increased level of creativity. Identifying such behavior will shed light on the mechanism of how CSE links to creativity (Chiang et al., 2014). In this study, we focus on employees' knowledge sharing behavior. Whereas previous research has suggested that altruistic knowledge sharing could facilitate the creativity of the knowledge recipient, the team and the organization (Oldham, 2003; Wang \& Noe, 2010), it is still unstudied as to whether knowledge sharing fosters the sharer's own creativity. A learning perspective (Shah, Cross, \& Levin, 2018) suggests that knowledge sharing does not only enable the knowledge recipient to learn, but also helps the knowledge sharer to acquire new insights and skills, which will 


\section{RUNNING HEAD: CSE AND CREATIVITY}

ultimately facilitate their own creativity. Indeed, as knowledge sharing entails both benefits (e.g., expected organizational rewards and enjoyment in helping others, Lin, 2007) and costs (e.g., loss of time and energy, Kankanhalli, Tan, \& Wei, 2005), not everyone is motivated to share their knowledge. We argue that high-CSE individuals might be more attentive to the benefits than the costs of knowledge sharing (Ferguson \& Bargh, 2008) and are thus more likely to share knowledge with their coworkers than low-CSE individuals. This process will ultimately increase their own creativity.

Last but not least, only a limited number of studies have examined the contingencies that activate or strengthen individuals' approach tendencies (Aryee et al., 2017; Ferris et al., 2011). In this study, we examine work meaningfulness as such a contingency. The theory of work meaningfulness (Steger \& Dik, 2010) suggests that work not only provides a sense of comprehension, which may aid people in utilizing their positive evaluations about abilities and competence to exhibit prosocial acts (e.g., knowledge sharing), but also offers a sense of purpose, which may highlight the prosocial impact of knowledge sharing and improve the understanding that their work is serving for the greater social good. We argue that work meaningfulness magnifies the prosocial benefits of knowledge sharing to individuals, thus making them share more knowledge with coworkers. Our hypothesized model is depicted in Figure 1.

Insert Figure 1 about here

Our study makes several important contributions to the literature. First, whereas most prior research focuses on task performance and organizational citizenship behaviors as the performance outcomes of CSE, our study examines creativity as an equally, if not more, critical performance outcome of CSE. Noting the lack of performance breadth in CSE 


\section{RUNNING HEAD: CSE AND CREATIVITY}

studies, several scholars have called for more research to expand the performance criterion space of CSE, in order to explicate its implications for a changing organizational environment (Aryee et al., 2017; Chang et al., 2012; Judge \& Kammeyer-Mueller, 2011). Our study contributes to the CSE literature by responding to these calls and provides empirical evidence that show how creativity could be a pivotal and distal performance outcome of CSE.

Second, by integrating the approach/avoidance framework of CSE and learning perspective of creativity, we take a further step to explain how CSE is linked to creativity. While previous research has stressed the importance of motivation among other things in explaining creativity (Amabile, 1988; Amabile \& Pratt, 2016) and examined how work environment and job characteristics influence individual's motivation (cf. Anderson et al., 2014), the implications of personality such as CSE for motivation and subsequently, for creativity-related behaviour and outcomes have not been fully considered (Chang et al., 2012). At the same time, scholars lament that research on CSE has been "mostly descriptive in nature" (Chang et al., 2012, p. 84) or "largely proceeded without much theoretical grounding" (Aryee et al., 2017, p. 948). The approach/avoidance framework (Elliot \& Thrash, 2002) provides a firm theoretical foundation for our study and explains from a motivational perspective why high-CSE individuals engage in knowledge sharing, a learning behavior that is critical for creativity (Shah et al., 2018). In doing so, we make a contribution to the literature through incorporating multiple theoretical perspectives into the CSE research.

Third, by identifying work meaningfulness as a boundary condition of the CSEknowledge sharing and CSE-creativity relationship, we respond to calls for more research on contextual variables that shape the personality-creativity relationship (Anderson et al., 2014) and research on contingencies that activate individuals' approach tendencies (Ferris et al., 2011). As work meaningfulness represents a perception that one's work can make a difference to others, it highlights the benefits of knowledge sharing and activates people's 


\section{RUNNING HEAD: CSE AND CREATIVITY}

approach temperaments to propel their knowledge sharing behaviors. The strengthened CSEknowledge sharing relationship further elicits creativity. By revealing the moderator between CSE and knowledge sharing, as well as the moderated mediation effects of CSE on creativity, we advance the currently incomplete knowledge of how and when CSE affects its outcomes (Chang et al., 2012).

Fourth and finally, this study adds to our understanding of personality and selfconcept as antecedents of creativity. Following an actor-centered approach, research has documented a range of personality characteristics as the antecedents of creativity, such as proactive personality (e.g., Kim, Hon, \& Crant, 2009), creative personality (Madjar, Oldham, \& Pratt, 2002) and big-five personality (see Anderson et al., 2014 for a review). In contrast to these previously-documented personality antecedents of creativity, CSE represents a broader and latent personality trait that includes the components of self-esteem, generalized selfefficacy, locus of control, and emotional stability (Judge et al., 2000). While research has investigated the relationships between some components of CSE and creativity, the returned results are inconclusive (Anderson et al., 2014). This suggests a need to take a more comprehensive view at CSE and its relationship with creativity, as CSE is a more global positive self-concept and is thus suggested to be a better predictor of work-related outcomes (Judge, 2009; Rode, Judge, \& Sun, 2012). In addition, aside from being distinct from creativity-specific self-concepts (e.g., creative self-efficacy, Tierney \& Farmer, 2002), CSE further represents a general self-concept that represents a baseline appraisal that implicitly exists in all personal beliefs and evaluations (Chang et al., 2012). Adding CSE to the "limited set of individual differences... for creativity" (Anderson et al., 2014, p. 1309) and uncovering the "black box" of its effect on creativity, our study advances our understanding of the role of personality in creativity.

\section{THEORETICAL BACKGROUND AND HYPOTHESES}




\section{RUNNING HEAD: CSE AND CREATIVITY}

\section{CSE and Knowledge Sharing}

Core self-evaluation (CSE) refers to people's fundamental evaluations of their own ability, competence and values (Judge et al., 1998). It is a global and latent personality construct representing a positive baseline evaluation in which they are self-potent, selfworthy, free from anxiety, and in control of their own lives (Harris, Harvey, \& Kacmar, 2009; Johnson, Rosen, \& Levy, 2008; Kim, Liden, Kim, \& Lee, 2015). Individuals with high CSE appraise themselves favorably as competent, valuable, and in control of their own lives (Judge \& Hurst, 2007; Judge, Van Vianen, \& De Pater, 2004). A recent meta-analysis found significant relationships of CSE with various job-related outcomes, such as in-role and extrarole job performance and job and life satisfaction (Chang et al., 2012). Indeed, CSE has been considered as an important personality construct (Chang et al., 2012; O’Neill, McLarnon, Xiu, \& Law, 2016) and is suggested to predict work-related outcomes better than other individual personality traits in both Eastern and Western contexts (Judge, 2009; Rode et al., 2012). In the current study, we follow the suggestions by previous scholars (Judge et al., 2000; Johnson et al., 2008; Chang et al., 2012) and treat CSE as a global trait, rather than four specific traits (i.e., self-esteem, generalized self-efficacy, locus of control and emotional stability) to capture the effects of an individual's overall positive evaluations on knowledge sharing and subsequently, on creativity.

We draw on the approach/avoidance framework (Elliot \& Thrash, 2002) to predict the relationship between CSE and knowledge sharing. The approach/avoidance framework asserts that the personality traits reflect orthogonal biologically based approach-andavoidance temperaments and can be categorized in terms of their respective sensitivities to positive or negative information (Chang et al., 2012; Elliot \& Thrash, 2002). For example, extroverted people are more sensitive to positive information while individuals with high levels of neuroticism are more sensitive to negative information. In relation to this, scholars 


\section{RUNNING HEAD: CSE AND CREATIVITY}

have revealed that individuals with approach temperaments tend to attend to the associated benefits than the possible costs when deciding whether to engage in certain behaviors (Ferguson \& Bargh, 2008). This helped to explain, for instance, why people engage in job crafting (Bipp \& Demerouti, 2015) and feedback seeking (Janssen \& Prins, 2007) in organizational settings.

Ferris and colleagues (2011) found that higher CSE is related to a stronger approach temperament and a weaker avoidance temperament. Thus individuals with high CSE are sensitive to positive information and insensitive to negative information. On the contrary, individuals with low CSE are sensitive to negative information and insensitive to positive information. This explains, for example, why high-CSE individuals are more likely to engage in in-role performance behaviors, OCBs and less likely to display deviance behaviors (Ferris et al., 2011). Chang et al. (2012) delineates that the approach/avoidance theoretical framework is useful in explaining the relationship between CSE and its outcomes due to the differential sensitivities to positive and negative information that high/low CSE individuals possess.

Knowledge sharing is a personal initiative to share one's own information, skills, and expertise with others (Lu, Leung, \& Koch, 2006; Wang \& Noe, 2010). It focuses on providing information and know-how to help others and to collaborate with others to solve problems, develop new ideas, or implement policies or procedures (Cummings, 2004). Knowledge sharing entails both benefits and costs. First, researchers have found that knowledge sharing is associated with organizational rewards that recognize employees' contribution of knowledge to the organization (Kankanhalli et al., 2005). Further, the sharing of knowledge presents learning opportunities to the knowledge sharer. To be able to effectively share the knowledge to their coworkers, individuals need to understand it well first so that they could organize and explain the knowledge in a clear way to ensure that the 


\section{RUNNING HEAD: CSE AND CREATIVITY}

knowledge recipient can understand it (Wang \& Noe, 2010). In the process of preparing to share the knowledge with their coworkers, individuals can deepen their understanding of the knowledge. The time spent in helping others with their own knowledge may enable them to obtain new insights and skills (Bolino \& Grant, 2016). In addition, sharing knowledge is a good way to elevate enjoyment and increase personal reputation (Lin, 2007), and may also serve to help build interpersonal reciprocity with coworkers and manage a positive impression in front of others (Wang \& Noe, 2010). Finally, by sharing knowledge, the knowledge sharer could help their peers gain new skills and expertise, which could in turn improve the team performance (Mesmer-Magnus, \& DeChurch, 2009).

On the other hand, there are several costs associated with knowledge sharing. One such cost is on the basis that knowledge can be a source of superior power (Gupta \& Govindarajan, 2000). An employee's distinctive knowledge can earn him/her higher performance evaluation and increased rewards and promotion opportunities (Husted \& Michailova, 2002; Wang \& Noe, 2010). The potential downside of sharing their unique knowledge is losing one's advantages of possessing this exclusive knowledge. Therefore, people may be reluctant to share knowledge due to the fear of losing their relative power (Kankanhalli et al., 2005). In addition, knowledge sharing costs time and efforts, which are spent on helping the knowledge recipient to understand the source's knowledge (Reagan \& McEvily, 2003). Finally, knowledge sharing also entails social costs. As suggested by Wang and Noe (2010), in the process of sharing knowledge, inconsistent perspectives may occur. These inconsistencies may not only reveal the mistakes made by the knowledge sharer or the recipient, but may also create disagreements and conflicts, which, if not handled well, could damage the social relations between them.

When evaluating the decision on whether to engage in knowledge sharing behavior, high-CSE individuals, driven by their strong approach temperaments and weak avoidance 


\section{RUNNING HEAD: CSE AND CREATIVITY}

temperaments, are more attentive to the positive side of knowledge sharing (Judge, Bono, Erez, \& Locke, 2005) and less attentive to the negative side. To them, the benefits of knowledge sharing are likely to be more salient and their choice is more driven by the benefits associated with knowledge sharing than the related costs. As a result, individuals with a high level of CSE are more likely to share their knowledge. In summary, we propose:

Hypothesis 1: CSE is positively related to knowledge sharing.

\section{CSE, Knowledge Sharing, and Creativity}

Creativity is the intentional generation of novel and useful ideas for products, processes and procedures (Amabile, 1988; Anderson et al., 2014). We argue that knowledge sharing can enhance the sharer's creativity through three mechanisms. First, sharing knowledge with coworkers is a useful learning opportunity. One may not be able to explain something lucidly to his or her coworkers unless he/she can thoroughly understand it him/herself. Thus, knowledge sharing could serve as a great opportunity for employees to extend his/her own understanding of the knowledge (Wang \& Noe, 2010). Second, knowledge recipients can provide timely feedback on refining and applying the original knowledge to the knowledge sharer (Lu, Lin, \& Leung, 2012; Radaelli, Lettieri, Mura, \& Spiller, 2014). This will help the sharer to develop better understandings of the questions encountered, generate new approaches to interpret previous views, and/or integrate previous understandings into a new framework (Du Plessis, 2007). Third and finally, inconsistencies in views and knowledge may be found during knowledge sharing. These disagreements are likely to facilitate the development of new ideas (Wang \& Noe, 2010). In summary, through the communication of views and exchange of information, knowledge sharing enables the knowledge sharer to update his/her knowledge and skills (Perry-Smith \& Shalley, 2003), which is a necessary precondition for generating creative ideas (Amabile, 1988).

Combining the previous arguments, we suggest that knowledge sharing mediates the 


\section{RUNNING HEAD: CSE AND CREATIVITY}

relationship between CSE and creativity. That is, individuals with high CSE are more likely to share their knowledge with others because they are more sensitive to the benefits over costs of knowledge sharing. By doing so, they are more likely to produce novel and useful ideas. Thus, we propose:

Hypothesis 2: Knowledge sharing mediates the positive relationship between CSE and creativity.

\section{The Moderating Role of Work Meaningfulness}

Work meaningfulness refers to the amount of significance and positive meaning that work holds for an individual (Pratt \& Ashforth, 2003; Rosso, Dekas, \& Wrzesniewski, 2010). Meaningful work is regarded as purposeful and significant. It leads to people's positive reflection on their work (Jiang \& Johnson, 2018) and affords individuals the opportunity to transcend their individual selves and connect with something that is greater (Michaelson, Pratt, Grant, \& Dunn, 2014; Pratt \& Ashforth, 2003). According to Steger and Dik (2010), work meaningfulness indicates a sense of work comprehension (i.e., a clear understanding of his or her role in the organization) and a sense of purpose (i.e., an understanding that they are serving for the greater social good). Prior research (May, Gilson, \& Harter, 2004; Steger, Littman-Ovadia, Miller, Menger, \& Rothmann, 2013) has found that work meaningfulness accounts for additional variances beyond organizational commitment and calling when predicting job satisfaction, absenteeism, and life satisfaction. In addition, work meaningfulness has been shown to influence numerous favorable job-related outcomes, such as engagement, empowerment, job satisfaction, work motivation, job performance, and career development (for a review, see Rosso et al., 2010). Scholars have also called for explorations of the role of work meaningfulness in employee creativity (Cohen-Meitar, Carmeli, \& Waldman, 2009). 


\section{RUNNING HEAD: CSE AND CREATIVITY}

In the current study, we propose that work meaningfulness moderates the relationship between CSE and knowledge sharing. When individuals see their work as meaningful, they clearly understand their role in the bigger organization and see the prosocial impact of their work on others' and the organizational aims, or more universal ones (Ashforth \& Vaidyanath, 2002). High work meaningfulness thus likely situates the benefits of knowledge sharing within a bigger picture. It helps individuals to gain a better understanding of how knowledge sharing behavior could positively impact their coworkers and the organization, or even a greater cause, which could lead to their stronger sense of accomplishment. As a result, individuals' motivation to engage in knowledge sharing behavior is enhanced. They will more successfully utilize the positive evaluations of their competence and turn them into knowledge sharing behavior. Therefore, we propose that the relationship between CSE and knowledge sharing is strengthened when employees experience higher work meaningfulness.

Hypothesis 3: Work meaningfulness moderates the positive relationship between CSE and knowledge sharing such that the positive relationship is stronger when work meaningfulness is higher.

Given the moderation hypothesis (i.e., Hypothesis 3) and the notion that work meaningfulness enhances the approach motivation of CSE, work meaningfulness could also strengthen the indirect relationship between CSE and creativity through knowledge sharing, thereby demonstrating a pattern of moderated mediation.

Hypothesis 4: Work meaningfulness moderates the positive indirect effect of CSE on creativity through knowledge sharing, such that this indirect effect is stronger when work meaningfulness is higher.

\section{METHODS}

\section{Research Procedures and Participants}

We collected data from a sample of researchers in a physics research institution in 


\section{RUNNING HEAD: CSE AND CREATIVITY}

northern China. Researchers serve as an excellent sample for testing our proposed model because creativity is a crucial component of their work. These researchers' daily job includes generating creative research ideas. They engage in providing suggestions and comments on others' ideas and seeking the same from others. We distributed the study information sheet and questionnaires to 300 researchers at time 1 and their direct supervisors at time 2 (three months after time 1) along with a letter of confidentiality and voluntary participation. At Time 1, a total of 256 (85.3\% response rate) questionnaires measuring participants' demographics, CSE, knowledge sharing and work meaningfulness were returned. At Time 2, supervisor questionnaires with ratings on subordinates' creativity were returned. Matching subordinate and supervisor responses resulted in 212 effective dyads. Twelve incomplete questionnaires were deleted. Hence, the final matched sample size was 200 dyads $(66.7 \%$ response rate). All assessments were conducted in Chinese. Most of the scales have been validated in the Chinese context by previous studies. Where it has not, the translation and back-translation processes were followed to ensure the quality of the translation (Brislin, Lonner, \& Thorndike, 1973).

The majority of participants were male (69.5\%). Fifty-three percent of the participants were unmarried. Fifty-three percent were under 30 years old, 39\% were between 30 and 40 years old and $4.5 \%$ were over 40 years old. In terms of education level, $45.5 \%$ of them held a doctoral degree, $37 \%$ held a master's degree and $17.5 \%$ held a bachelor's degree.

\section{Measures}

\section{CSE (Employee rating, T1)}

We assessed CSE with 12-item Core Self-Evaluation Scale (CSES; Judge, Erez, Bono, \& Thoresen, 2003). The measure has been validated by Rode et al. (2012) in the Chinese context. The 12 items were scored on a five-point Likert scale ranging from " 1 " (strongly disagree) to "5" (strongly agree). A sample item was "When I try, I generally 
RUNNING HEAD: CSE AND CREATIVITY

succeed”. The Cronbach's alpha was .86.

\section{Knowledge Sharing (Employee rating, T1)}

We measured knowledge sharing with 8 items from the scale developed by Lu et al. (2006) using a Chinese sample. Sample items included "I actively share my knowledge with my colleagues". The items were each measured using a six-point Likert scale, ranging from "1" (strongly disagree) to "6" (strongly agree). The Cronbach's alpha was .89.

\section{Work Meaningfulness (Employee rating, T1)}

Work meaningfulness was measured with 10 items using the Work and Meaning Inventory (WAMI) developed by Steger, Dik and Duffy (2012). Each item was scored on a six-point Likert scale ranging from "1" (strongly disagree) to "6" (strongly agree). Sample items were "I have a good sense of what makes my job meaningful" and "My work helps me better understand myself'. The Cronbach's alpha of the scale was .95 .

\section{Creativity (Supervisor rating, T2)}

Creativity was measured with Farmer, Tierney and Kung-Mcintyre's (2003) 4 items on six-point Likert scale from " 1 " (strongly disagree) to "6" (strongly agree). A sample item is “(This employee) Tries new ideas or methods first". The Cronbach's alpha of the scale was .89 .

\section{RESULTS}

\section{Confirmatory Factor Analyses (CFA)}

We conducted a series of CFAs in Mplus 7 (Muthén, \& Muthén, 2012) to examine the construct validity of the latent variables in this study: CSE, knowledge sharing, work meaningfulness and creativity. Because our sample size is relatively small (Williams, Vandenberg, \& Edwards, 2009) and the ratio of sample size to parameters (i.e., 200/150= 1.33 ) is below the recommended value of 5 (Bentler \& Chou, 1987), we created parcels for latent variables before testing the competing models. Although item parcels have been 


\section{RUNNING HEAD: CSE AND CREATIVITY}

criticized for the lack of meaning (Williams, Vandenberg, \& Edwards, 2009) and misspecification possibilities (Marsh, Lüdtke, Nagengast, Morin, \& Von Davier, 2013), Little, Rhemtulla, Gibson and Schoemann (2013) argue that parcels have higher reliability due to the aggregation of items and structural models with parcels have reduced sources of sampling error. If the goal is to understand the relationship between constructs instead of item-level relationships, they argue that well-applied parceling is advantageous in providing "a parsimonious representation of the construct"' (Little et al., 2013, p. 294).

Following the recommended parceling strategies of Little et al. (2013), we applied theory-guided parceling and also used EFA results to aid our parceling decisions. Specifically, we created three parcels for work meaningfulness based on its three dimensions. In addition, we used the single-factor method recommended by Landis and colleagues (2000) to create parcels for CSE and knowledge sharing. We first ran an exploratory factor analysis (EFA) wherein a single-factor solution was specified. Then, we assigned the item with the highest factor loading to the first parcel, the second highest loading to the second parcel, and so forth until all items were assigned to form two balanced parcels. Consequently, we created two parcels for CSE and knowledge sharing, respectively. The Chi-square difference tests showed that the four-factor baseline model yielded superior fit than alternative models (See Table 1), providing evidence for the adequate construct validity of the theoretical constructs in our study.

Insert Table 1 about here

\section{Hypothesis Testing}

Table 2 reported the means, standard deviations, reliabilities, and correlations of all variables. Notably, CSE was positively correlated with knowledge sharing $(r=.53, p<.01)$ 


\section{RUNNING HEAD: CSE AND CREATIVITY}

and creativity $(r=.26, p<.01)$. In addition, knowledge sharing was positively correlated with creativity $(r=.29, p<.01)$.

Insert Table 2 about here

We conducted structural equation modeling (SEM) analyses in Mplus 7 to test our hypotheses. To test hypothesis 1 , we estimated a direct effect model in which knowledge sharing was predicted by CSE. The results showed that CSE was positively related to knowledge sharing $(B=.70, p<.01)$, supporting hypothesis 1 .

We tested hypothesis 2 following the suggestions by Preacher and Hayes (2008). Preacher and Hayes (2008) proposed three conditions for the mediation effect to hold: the independent variable should be significantly related to the mediator, the mediator should be significantly related to the dependent variable, and the indirect effect of the independent variable on the dependent variable should be significant when the mediator is present. The first condition was met because of the support for hypothesis 1 . We tested both full mediation and partial mediation models for hypothesis 2 . Specifically, we first examined a partial mediation model in which knowledge sharing was predicted by CSE, and creativity was predicted by CSE and knowledge sharing. The model had a good fit to the data: $\chi^{2}[12]$ $=29.999, p<.01, \mathrm{CFI}=.980, \mathrm{TLI}=.965, \mathrm{RMSEA}=.087, \mathrm{SRMR}=.033 . \mathrm{In}$ this model, CSE was positively related to creativity $(B=.30, p<.01)$, providing a preliminary support for the partial mediation model. Then, we tested a full mediation model in which there was no direct effect of CSE on creativity. The model yielded a good fit to the data: $\chi^{2}[13]=34.283, p<.01$, $\mathrm{CFI}=.976, \mathrm{TLI}=.962, \mathrm{RMSEA}=.090, \mathrm{SRMR}=.042$. The $\Delta \chi^{2}$ test showed that the partial mediation model had a better fit $\left(\triangle \chi^{2}[\triangle d f=1]=4.284, p<.05\right)$ than the full mediation model. Thus, we tested hypothesis 2 based on the partial mediation model. As expected, 


\section{RUNNING HEAD: CSE AND CREATIVITY}

knowledge sharing was positively related to creativity $(B=.31, p<.05)$. We further tested the indirect effect of CSE on creativity using the 95\% confidence intervals (CIs, 5000 bootstrapping samples). The results showed that the indirect effect of CSE on creativity was positive and significant (estimated indirect effect $=.21$, with a $95 \% \mathrm{CI}$ of $[.06, .42]$ ). Therefore, hypothesis 2 was supported.

To test the moderation hypothesis (i.e., hypothesis 3 ) and the moderated mediation hypothesis (i.e., hypothesis 4), a moderated mediation model was estimated based on the partial mediation model. All variables were centered before the analyses (Aiken \& West, 1991) to improve the interpretation of our results (Cohen, Cohen, West, \& Aiken, 2003; Dalal $\&$ Zickar, 2012). This model yielded a good fit to the data: $\chi^{2}[14]=30.458, p<.01, \mathrm{CFI}=.974$, $\mathrm{TLI}=.953, \mathrm{RMSEA}=.077, \mathrm{SRMR}=.031$. As shown in Figure 2, the interaction term (i.e., CSE $\times$ work meaningfulness) was significant $(B=.08, p<.05)$. Plotting the interaction effect (see Figure 3) shows that employees who experience high work meaningfulness (1 SD above the mean) demonstrated a stronger relationship between CSE and knowledge sharing $(B=.29, p$ $<.01$ ) than those with low work meaningfulness (1 SD below the mean, $B=.13$, n.s.), supporting hypothesis 3 (see Figure 3).

Insert Figures 2 and 3 about here

Hypothesis 4 predicted that the indirect effect of CSE on creativity through knowledge sharing will be moderated by work meaningfulness. That is, we expected the mediation effect of knowledge sharing would vary at different levels of work meaningfulness (Preacher, Rucker, \& Hayes, 2007). Again, we examined the 95\% CIs with 5000 bootstrapping samples.

According to the procedures suggested by Edwards and Lambert (2007), moderated 


\section{RUNNING HEAD: CSE AND CREATIVITY}

mediation is supported if the indirect effect of CSE on creativity via knowledge sharing differs significantly between low and high levels of the moderators (i.e., work meaningfulness). We tested the conditional indirect effect at two levels of work meaningfulness (-1 SD and $+1 \mathrm{SD})$. The results were shown in Table 3. As predicted, the indirect effect was not significant $[B=.04,95 \% \mathrm{CI}=(-.01,14)]$ when work meaningfulness was low, but was significant $[B=.08,95 \% \mathrm{CI}=(.02,19)]$ when work meaningfulness was high. The difference between the indirect effects was $.05(95 \% \mathrm{CI}=[.004, .12])$, excluding 0 , indicating that the moderated mediation was supported (Hayes, 2015). Thus, hypothesis 4 was supported.

Insert Table 3 about here

\section{Robustness Check}

Following recent recommendations on the use of control variables (e.g., Becker, Atinc, Breaugh, Carlson, Edwards, \& Spector, 2016; Bernerth, \& Aguinis, 2016; Carlson \& Wu, 2012), we did robustness check using SEM and tested our hypotheses after including the control variables in the analyses. Specifically, employee demographics including gender $(0=$ female, $1=$ male $)$, age $(1=30$ years and below, $2=31$ to 40 years, $3=41$ years and above $)$, education level $(1$ = bachelor degree, 2 = master degree, 3 = doctoral degree $)$ and marital status $(1=$ married, 2 = not married) were controlled. Gender (Baer \& Kaufman, 2008), age (Jones \& Weinberg, 2011) and educational differences (Tierney \& Farmer, 2002) in creativity have been found in previous studies. Research also found that married employees exhibited higher creativity, possibly because they experienced more psychological safety and therefore, were more risk-taking (Madjar, Oldham, \& Pratt, 2002). The correlations among controls and other variables were presented in Table 2 . 


\section{RUNNING HEAD: CSE AND CREATIVITY}

The results showed that CSE was related to knowledge sharing $(B=.68, p<.01)$, supporting hypothesis 1 . For hypothesis 2 , in the partial mediation model, knowledge sharing was positively related to creativity $(B=.27, p<.05)$, and the indirect effect of CSE on creativity was .18, with a $95 \%$ CI of $[.03,38]$. Therefore, hypothesis 2 was also supported. In the moderated mediation model, the interaction between CSE and work meaningfulness was still positively related to knowledge sharing $(B=.09, p<.05)$, supporting hypothesis 3 . The moderated mediation analysis results indicated that the indirect effect of CSE on creativity via knowledge sharing was not significant $[B=.03,95 \% \mathrm{CI}=(-.01,13)]$ when work meaningfulness was low, but was significant $[B=.08,95 \% \mathrm{CI}=(.01,19)]$ when work meaningfulness was high. The difference between the indirect effects was $.05(95 \% \mathrm{CI}=$ $[.003, .13])$, supporting hypothesis 4 . In summary, all hypotheses held after including control variables in the analyses.

\section{DISCUSSION}

Drawing on the approach/avoidance framework and the learning perspective of creativity, we expected that knowledge sharing mediated the relationship between CSE and creativity. Using a sample of 200 researchers and their supervisors, we found evidence for a partially mediated relationship. In addition, our results showed that work meaningfulness strengthened the relationship between CSE and knowledge sharing, as well as the indirect relationship between CSE and creativity via knowledge sharing. The hypothesized relationships remained significant after control variables were removed from the model. The results provide several important theoretical and practical implications.

\section{Theoretical Implications}

First, our study enriches CSE research by adding further evidence that CSE, as an important and distinct broader personality construct that captures employees' general positive self-concept, contributed to predicting individual creativity (Chiang et al., 2014). Although 


\section{RUNNING HEAD: CSE AND CREATIVITY}

the componential theory of creativity (Amabile, 1988; 1996) asserts that personality has a significant impact on individuals' engagement in innovation-related activities and previous work has examined a number of personality variables (Anderson et al., 2014), little work has been undertaken to examine the role of CSE. The current findings address this limitation and extend the creativity literature by showing that the global evaluations about oneself capture a distinct personal attribute that contributes to generating creative ideas. As the outcome of creativity is inherently uncertain (Zhou \& George, 2001) and creative action is often a choice (cf. Ford, 1996), positive evaluations of oneself appear crucial. Different from creativityspecific self-evaluations, such as creative self-efficacy, which are narrower in nature and can be more easily affected by the environment (Tierney \& Farmer, 2002), CSE represents more fundamental and stable evaluations of oneself in broader areas (Judge et al., 1998) and is an effective predictor of creativity-related behaviors. Building on our findings, future research may be conducted on other workplace behaviors that entail both benefits and risks, for example, unethical pro-organizational behavior (Umphress, Bingham, \& Mitchell, 2010).

Second, drawing on the approach/avoidance framework, our model extends earlier research by revealing knowledge sharing as one particular mechanism between CSE and creativity. Although knowledge sharing has been suggested to be beneficial for recipients' and team-level creativity (Dong, Bartol, Zhang, \& Li, 2017), its role in benefiting the knowledge sharer's creativity has received limited empirical support. Recently, Shah et al. (2018) found that providing problem-solving assistance to coworkers increased the sharer's learning and knowledge base. Conversely, hiding knowledge from coworkers hurts one's own creativity (Černe, Nerstad, Dysvik, \& Škerlavaj, 2014). Consistent with these findings, our study reveals that knowledge sharing benefits one's own creativity. Knowledge sharing boosts communication with coworkers and builds relational resources of the knowledge sharer. The knowledge sharer receives constructive and prompt feedback, as well as instrumental and 


\section{RUNNING HEAD: CSE AND CREATIVITY}

emotional support as a return from their coworkers, which are all essential for the creation of new ideas (Shah et al., 2018). Future research could build on our findings to take a finegrained look at these mechanisms linking knowledge sharing and creativity using a longitudinal study design. Understanding the mechanisms would contribute to the advancement and refinement of the approach/avoidance framework through the delineation of how CSE relates to desirable work-related outcomes.

Finally, this study further identified the novel moderating role of work meaningfulness in the relationship between CSE and knowledge sharing and of the indirect effect CSE had on creativity. Employees who reported experiencing their work as more meaningful shared more knowledge with their coworkers, elicited by their strengthened sensitivity to the benefits of knowledge sharing, which derives from a better understanding of the impact of their work. In contrast, there was no relationship observed between CSE and knowledge sharing when work meaningfulness was low. The indirect effect of CSE on creativity exhibited similar patterns: it was not significant when work meaningfulness was low, but was positive and significant when work meaningfulness was high. It appears that high work meaningfulness activates the approach tendencies of high-CSE individuals. Indeed, preliminary findings suggest that "the beneficial effects of approach constructs are contingent upon incentive or rewards that activate approach tendencies" (Ferris et al., 2011, p: 156). Our findings contribute to the development and clarification of when approach constructs (e.g., CSE) lead to desirable outcomes by uncovering work meaningfulness as such an essential incentive.

\section{Practical Implications}

The current research also carries several practical implications. First, the findings suggest that high CSE employees are more likely to display knowledge sharing and benefit from it. As CSE is a rather stable personality trait, this may provide implications for recruitment and selection practices, since it is expected that individuals high on CSE will 


\section{RUNNING HEAD: CSE AND CREATIVITY}

"show some consistency in behavior long after they have been hired, and in a variety of jobs and work roles" (Judge \& Kammeyer-Mueller, 2011, p. 332). One reasonable recommendation is that managers could consider hiring individuals with a high level of CSE if the job requires creativity, provided that other more important selection criteria have been met. We expect that these individuals will engage in knowledge sharing more often if adequate incentives are present, thus benefiting both coworkers' and their own creativity.

Second, the results of this study suggest that work meaningfulness is beneficial to activating and releasing the positive potential of CSE. Pratt and Ashforth (2003) propose a range of "meaningfulness in working practices" and "meaningfulness at work practices". The former category of practices includes job design, employee involvement practices and goalpath leadership (House, 1997). They change what workers do. When used in a systematic manner, they can potentially nurture "callings" (Wrzesniewski, McCauley, Rozin, \& Shwarz, 1997) and render maximal work meaningfulness. The latter category of practices includes, for example, visionary leadership and community building. They shape the context in which work is done. Organizations can thus adopt these practices to increase employees' work meaningfulness as a way to activate their approach tendencies and increase their knowledge sharing behavior. As knowledge sharing behavior is observable, managers can compare the frequency of employees' knowledge sharing before and after the managerial interventions and establish their effectiveness.

Third and finally, as knowledge sharing can promote creativity, it is recommended that organizations encourage employees to share their knowledge and provide a supportive climate for knowledge sharing in order to help employees to develop the knowledge and skills necessary for creating novel ideas and implementing those ideas. This implication is supported by empirical findings that firms that promote knowledge sharing practices within groups or organizations is likely to generate new ideas for developing new business 
RUNNING HEAD: CSE AND CREATIVITY

opportunities, which can further facilitate innovative activities (Heffner \& Sharif, 2008; Lundvall \& Nielsen, 2007).

\section{Limitations and Future Directions}

The implications above should be interpreted in light of the limitations of this study. First, some limitations exist with regard to our research design and analytical approach, thus our findings should be interpreted with caution. Because our sample is relatively small and the sample-to-parameter ratio is low, we conducted our CFA and SEM analyses with parceling strategies. We encourage future research to test the model with a larger sample without using item parcels and compare the results. Moreover, we used supervisory ratings to measure individual creativity, which has been suggested as an advance in creativity measurement in recent years (cf. Anderson et al., 2014). That being said, where appropriate, future research should adopt more objective measures of creativity (e.g., number of patents) to reduce rater bias (Park, Chun, \& Lee, 2016). In addition, the temporal separation and multi-source design reduced the common method variance between variables collected at Time 1 and Time 2 (Podsakoff, MacKenzie, \& Podsakoff, 2012; Podsakoff, MacKenzie, Lee, \& Podsakoff, 2003; Spector, 2006), nevertheless, concerns exist with regard to the variables collected at Time 1. Specifically, although CFA results suggest that our findings are not unduly influenced by common method bias and the moderated mediation effect is less influenced by common method variance (Evans, 1985), future studies should attempt to replicate our findings by using more rigorous longitudinal designs with multi-source data.

Second, while the moderators and mediators we examined were theoretically-driven, there could be other moderators and mediators that may be relevant in understanding the links connecting CSE and creativity. For example, a desirable work environment may serve as a crucial boundary condition because an effective environment (e.g., free of politics) is helpful in maintaining positive cognitions and activating approach tendencies to invoke creativity 
RUNNING HEAD: CSE AND CREATIVITY

(Kacmar, Collins, Harris, \& Judge, 2009). Furthermore, high-CSE individuals tend to have higher levels of persistence (Wanberg, Glomb, Song, \& Sorenson, 2005), which in turn may lead to higher creativity (De Dreu, Baas, \& Nijstad, 2008). Therefore, future research should continue to explore other relevant moderators and mediators.

\section{CONCLUSION}

Drawing on the approach/avoidance framework, our study revealed that CSE enhanced employees' creativity through knowledge sharing when they experienced high work meaningfulness. The findings improve our understanding of the link between CSE and creativity by uncovering the underlying mechanism and delineating the boundary condition. This study encourages future research to examine the relationship between CSE and creativity as well as the underlying mechanisms and boundary conditions. 


\section{REFERENCES}

Aiken, L. S., \& West, S. G. (1991). Multiple regression: Testing and interpreting interactions. Newbury Park, CA: Sage.

Amabile, T. M. (1988). A model of creativity and innovation in organizations. Research in Organizational Behavior, 10, 123-167.

Amabile, T. M. (1996). Creativity in context. Boulder, CO: Westview.

Amabile, T. M., \& Pratt, M. G. (2016). The dynamic componential model of creativity and innovation in organizations: Making progress, making meaning. Research in Organizational Behavior, 36, 157-183. https://doi.org/10.1016/j.riob.2016.10.001

Amabile, T. M., Schatzel, E. A., Moneta, G. B., \& Kramer, S. J. (2004). Leader behaviors and the work environment for creativity: Perceived leader support. The Leadership Quarterly, 15, 5-32.https://doi.org/10.1016/j.leaqua.2003.12.003

Anderson, N., De Dreu, C. K., \& Nijstad, B. A. (2004). The routinization of innovation research: A constructively critical review of the state-of-the-science. Journal of Organizational Behavior, 25, 147-173. https://doi.org/10.1002/job.236

Anderson, N., Potočnik, K., \& Zhou, J. (2014). Innovation and creativity in organizations a state-of-the-science review, prospective commentary, and guiding framework. Journal of Management, 40, 1297-1333. https://doi.org/10.1177/0149206314527128

Aryee, S., Walumbwa, F. O., Mondejar, R., \& Chu, C. W. (2017). Core self-evaluations and employee voice behavior test of a dual-motivational pathway. Journal of Management, 43, 946-966. https://doi.org/10.1177/0149206314546192

Ashforth, B. E., \& Vaidyanath, D. (2002). Work organizations as secular religions. Journal of Management Inquiry, 11, 359-370. https://doi.org/10.1177/1056492602238843

Baer, J., \& Kaufman, J. C. (2008). Gender differences in creativity. The Journal of Creative Behavior, 42, 75-105. https://doi.org/10.1002/j.2162-6057.2008.tb01289.x 


\section{RUNNING HEAD: CSE AND CREATIVITY}

Becker, T. E., Atinc, G., Breaugh, J. A., Carlson, K. D., Edwards, J. R., \& Spector, P. E. (2016). Statistical control in correlational studies: 10 essential recommendations for organizational researchers. Journal of Organizational Behavior, 37(2), 157-167. https://doi.org/10.1002/job.2053

Bentler, P. M., \& Chou, C. P. (1987). Practical issues in structural modeling. Sociological Methods \& Research, 16, 78-117. https://doi.org/10.1177/0049124187016001004

Bernerth, J. B., \& Aguinis, H. (2016). A critical review and best-practice recommendations for control variable usage. Personnel Psychology, 69(1), 229-283. https://doi.org/10.1111/peps.12103

Bipp, T., \& Demerouti, E. (2015). Which employees craft their jobs and how? Basic dimensions of personality and employees' job crafting behaviour. Journal of Occupational and Organizational Psychology, 88, 631-655. https://doi.org/10.1111/joop.12089

Bolino, M. C., \& Grant, A. M. (2016). The bright side of being prosocial at work, and the dark side, too: A review and agenda for research on other-oriented motives, behavior, and impact in organizations. Academy of Management Annals, 10, 599-670. https://doi.org/10.1080/19416520.2016.1153260

Brislin, R. W., Lonner, W., \& Thorndike, R. (1973). Cross-cultural methods. Publication John Wiley and Sons, New York.

Carlson, K. D., \& Wu, J. (2012). The illusion of statistical control: Control variable practice in management research. Organizational Research Methods, 15(3), 413-435. https://doi.org/10.1177/1094428111428817

Černe, M., Nerstad, C. G., Dysvik, A., \& Škerlavaj, M. (2014). What goes around comes around: Knowledge hiding, perceived motivational climate, and creativity. Academy of Management Journal, 57, 172-192. https://doi.org/10.5465/amj.2012.0122 
RUNNING HEAD: CSE AND CREATIVITY

Chang, C. H., Ferris, D. L., Johnson, R. E., Rosen, C. C., \& Tan, J. A. (2012). Core selfevaluations: A review and evaluation of the literature. Journal of Management, 38, 81128. https://doi.org/10.1177/0149206311419661

Chiang, Y. H., Hsu, C. C., \& Hung, K. P. (2014). Core self-evaluation and workplace creativity. Journal of Business Research, 67, 1405-1413. https://doi.org/10.1016/j.jbusres.2013.08.012

Cohen, J., Cohen, P., West, S. G., \& Aiken, L. S. (2003). Applied multiple correlation/regression analysis for the behavioral sciences. Hillsdale, NJ: Erlbaum.

Cohen-Meitar, R., Carmeli, A., \& Waldman, D. A. (2009). Linking meaningfulness in the workplace to employee creativity: The intervening role of organizational identification and positive psychological experiences. Creativity Research Journal, 21, 361-375. https://doi.org/10.1080/10400410902969910

Cummings, J. N. (2004). Work groups, structural diversity, and knowledge sharing in a global organization. Management science, 50, 352-364. https://doi.org/10.1287/mnsc. 1030.0134

Dalal, D. K., \& Zickar, M. J. (2012). Some common myths about centering predictor variables in moderated multiple regression and polynomial regression. Organizational Research Methods, 15, 339-362. https://doi.org/10.1177/1094428111430540

De Dreu, C. K., Baas, M., \& Nijstad, B. A. (2008). Hedonic tone and activation level in the mood-creativity link: toward a dual pathway to creativity model. Journal of Personality and Social Psychology, 94, 739-756. http://dx.doi.org/10.1037/0022$\underline{3514.94 .5 .739}$

Dewett, T. (2006). Exploring the role of risk in employee creativity. The Journal of Creative Behavior, 40, 27-45. https://doi.org/10.1002/j.2162-6057.2006.tb01265.x

Dong, Y., Bartol, K. M., Zhang, Z. X., \& Li, C. (2017). Enhancing employee creativity via 
RUNNING HEAD: CSE AND CREATIVITY

individual skill development and team knowledge sharing: Influences of dual-focused transformational leadership. Journal of Organizational Behavior, 38, 439-458. https://doi.org/10.1002/job.2134

Du Plessis, M. (2007). The role of knowledge management in innovation. Journal of Knowledge Management, 11, 20-29. https://doi.org/10.1108/13673270710762684

Ederer, F., \& Manso, G. (2013). Is pay for performance detrimental to innovation? Management Science, 59, 1496-1513. https://doi.org/10.1287/mnsc.1120.1683

Edwards, J. R., \& Lambert, L. S. (2007). Methods for integrating moderation and mediation: a general analytical framework using moderated path analysis. Psychological Methods, 12, 1-22. http://dx.doi.org/10.1037/1082-989X.12.1.1

Elliot, A. J., \& Thrash, T. M. (2002). Approach-avoidance motivation in personality: approach and avoidance temperaments and goals. Journal of Personality and Social Psychology, 82, 804-818. http://dx.doi.org/10.1037/0022-3514.82.5.804

Erez, A., \& Judge, T. A. (2001). Relationship of core self-evaluations to goal setting, motivation, and performance. Journal of Applied Psychology, 86, 1270-1279. DOI: $10.1037 / 0021-9010.86 .6 .1270$

Evans, M.G. (1985). A Monte Carlo study of the effects of correlated method variance in moderated multiple regression analysis. Organizational Behavior and Human Decision Processes, 36, 305-323. https://doi.org/10.1016/0749-5978(85)90002-0

Farmer, S. M., Tierney, P., \& Kung-McIntyre, K. (2003). Employee creativity in Taiwan: An application of role identity theory. Academy of Management Journal, 46, 618-630. https://doi.org/10.5465/30040653

Ferguson, M. J., \& Bargh, J. A. (2008). Evaluative readiness: the motivational nature of automatic evaluation. In A. J. Elliot (Ed.), Handbook of approach and avoidance motivation (pp. 289-306). New York: Psychology Press. 
Ferris, D. L., Rosen, C. R., Johnson, R. E., Brown, D. J., Risavy, S. D., \& Heller, D. (2011). Approach or avoidance (or both?): Integrating core self-evaluations within an approach/avoidance framework. Personnel Psychology, 64, 137-161. https://doi.org/10.1111/j.1744-6570.2010.01204.x

Ford, C. (1996). A theory of individual creative action in multiple social domains. Academy of Management Review, 21, 1112-1142. https://doi.org/10.5465/amr.1996.9704071865

Gupta, A. K., \& Govindarajan, V. (2000). Knowledge flows within multinational corporations. Strategic Management Journal, 21, 473-496. DOI: 10.1002/(SICI)1097$\underline{0266(200004) 21: 4 \% 3 C 473:: A I D-S M J 84 \% 3 E 3.0 . C O \% 3 B 2-I}$

Harris, K. J., Harvey, P., \& Kacmar, K. M. (2009). Do social stressors impact everyone equally? An examination of the moderating impact of core self-evaluations. Journal of Business and Psychology, 24, 153-164. https://doi.org/10.1007/s10869-009-9096-2

Heffner, M., \& Sharif, N. (2008). Knowledge fusion for technological innovation in organizations. Journal of Knowledge Management, 12, 79-93. https://doi.org/10.1108/13673270810859532

Hu, J., Wang, Z., Liden, R. C., \& Sun, J. (2012). The influence of leader core self-evaluation on follower reports of transformational leadership. Leadership Quarterly, 23, 860868. https://doi.org/10.1016/j.leaqua.2012.05.004

Husted, K., \& Michailova, S. (2002). Diagnosing and fighting knowledge-sharing hostility. Organizational Dynamics, 31, 60-73. DOI: 10.1016/S0090-2616(02)00072-4 Janssen, O., \& Prins, J. (2007). Goal orientations and the seeking of different types of feedback information. Journal of Occupational and Organizational Psychology, 80, 235-249. https://doi.org/10.1348/096317906X103410

Jiang, L., \& Johnson, M. J. (2018). Meaningful Work and Affective Commitment: A Moderated Mediation Model of Positive Work Reflection and Work 
RUNNING HEAD: CSE AND CREATIVITY

Centrality. Journal of Business and Psychology, 33, 545-558.

https://doi.org/10.1007/s10869-017-9509-6

Johnson, R. E., Rosen, C. C., \& Chang, C. H. (2011). To aggregate or not to aggregate: Steps for developing and validating higher-order multidimensional constructs. Journal of Business and Psychology, 26, 241-248. https://doi.org/10.1007/s10869-011-9238-1

Johnson, R. E., Rosen, C. C., \& Levy, P. E. (2008). Getting to the core of core selfevaluation: a review and recommendations. Journal of Organizational Behavior, 29, 391-413. https://doi.org/10.1002/job.514

Judge, T. A. (2009). Core self-evaluations and work success. Current Directions in Psychological Science, 18, 58-62. https://doi.org/10.1111/j.1467-8721.2009.01606.x Judge, T. A., Bono, J. E., Erez, A., \& Locke, E. A. (2005). Core self-evaluations and job and life satisfaction: the role of self-concordance and goal attainment. Journal of Applied Psychology, 90, 257-268. DOI: 10.1037/0021-9010.90.2.257

Judge, T. A., Bono, J. E., \& Locke, E. A. (2000). Personality and job satisfaction: The mediating role of job characteristics. Journal of Applied Psychology, 85, 237-249. http://dx.doi.org/10.1037/0021-9010.85.2.237

Judge, T. A., Erez, A., \& Bono, J. E. (1998). The power of being positive: The relation between positive self-concept and job performance. Human Performance, 11, 167187. https://doi.org/10.1080/08959285.1998.9668030

Judge, T. A., Erez, A., Bono, J. E., \& Thoreson, C. J. (2003). The core self-evaluations scale: Development of a measure. Personnel Psychology, 56, 303-332. https://doi.org/10.1111/j.1744-6570.2003.tb00152.x

Judge, T. A., \& Hurst, C. (2007). Capitalizing on one's advantages: role of core selfevaluations. Journal of Applied Psychology, 92, 1212-1227. DOI: 10.1037/0021$\underline{9010.92 .5 .1212}$ 


\section{RUNNING HEAD: CSE AND CREATIVITY}

Judge, T. A., \& Kammeyer-Mueller, J. D. (2011). Implications of core self-evaluations for a changing organizational context. Human Resource Management Review, 21, 331-341. https://doi.org/10.1016/j.hrmr.2010.10.003

Judge, T. A., Locke, E. A., \& Durham, C. C. (1997). The dispositional causes of job satisfaction: A core evaluations approach. Research in Organizational Behavior, 19, 151-188.

Judge, T. A., Van Vianen, A. E., \& De Pater, I. E. (2004). Emotional stability, core selfevaluations, and job outcomes: A review of the evidence and an agenda for future research. Human Performance, 17, 325-346. https://doi.org/10.1207/s15327043hup1703 4

Kacmar, K. M., Collins, B. J., Harris, K. J., \& Judge, T. A. (2009). Core self-evaluations and job performance: The role of the perceived work environment. Journal of Applied Psychology, 94, 1572-1580. http://dx.doi.org/10.1037/a0017498

Kankanhalli, A., Tan, B. C., \& Wei, K. K. (2005). Contributing knowledge to electronic knowledge repositories: an empirical investigation. MIS Quarterly, 29, 113-143.

Kim, T. Y., Hon, A. H., \& Crant, J. M. (2009). Proactive personality, employee creativity, and newcomer outcomes: A longitudinal study. Journal of Business and Psychology, 24, 93-103. https://doi.org/10.1007/s10869-009-9094-4

Kim, T. Y., Liden, R. C., Kim, S. P., \& Lee, D. R. (2015). The interplay between follower core self-evaluation and transformational leadership: Effects on employee outcomes. Journal of Business and Psychology, 30, 345-355. https://doi.org/10.1007/s10869-014-9364-7

Landis, R. S., Beal, D. J., \& Tesluk, P. E. (2000). A comparison of approaches to forming composite measures in structural equation models. Organizational Research Methods, 3, 186-207. https://doi.org/10.1177/109442810032003 


\section{RUNNING HEAD: CSE AND CREATIVITY}

Lin, H. F. (2007). Knowledge sharing and firm innovation capability: an empirical study. International Journal of Manpower, 28, 315-332. https://doi.org/10.1108/01437720710755272

Little, T. D., Rhemtulla, M., Gibson, K., \& Schoemann, A. M. (2013). Why the items versus parcels controversy needn't be one. Psychological Methods, 18, 285-300. DOI: $10.1037 / \mathrm{a} 0033266$

Lu, L., Leung, K., \& Koch, P. T. (2006). Managerial knowledge sharing: The role of individual, interpersonal, and organizational factors. Management and Organization Review, 2, 15-41. https://doi.org/10.1111/j.1740-8784.2006.00029.x

Lu, L., Lin, X., \& Leung, K. (2012). Goal orientation and innovative performance: The mediating roles of knowledge sharing and perceived autonomy. Journal of Applied Social Psychology, 42, E180-E197. https://doi.org/10.1111/j.1559-1816.2012.01018.x

Lundvall, B. Å., \& Nielsen, P. (2007). Knowledge management and innovation performance. International Journal of Manpower, 28, 207-223. https://doi.org/10.1108/01437720710755218

Madjar, N., Oldham, G. R., \& Pratt, M. G. (2002). There's no place like home? The contributions of work and nonwork creativity support to employees' creative performance. Academy of Management Journal, 45, 757-767. https://doi.org/10.5465/3069309

Marsh, H. W., Lüdtke, O., Nagengast, B., Morin, A. J., \& Von Davier, M. (2013). Why item parcels are (almost) never appropriate: Two wrongs do not make a rightCamouflaging misspecification with item parcels in CFA models. Psychological Methods, 18, 257-284. http://dx.doi.org/10.1037/a0032773

May, D. R., Gilson, R. L., \& Harter, L. M. (2004). The psychological conditions of meaningfulness, safety and availability and the engagement of the human spirit at 


\section{RUNNING HEAD: CSE AND CREATIVITY}

work. Journal of Occupational and Organizational Psychology, 77, 11-37. https://doi.org/10.1348/096317904322915892

Mesmer-Magnus, J. R., \& DeChurch, L. A. (2009). Information sharing and team performance: a meta-analysis. Journal of Applied Psychology, 94, 535-546. http://dx.doi.org/10.1037/a0013773

Michaelson, C., Pratt, M. G., Grant, A. M., \& Dunn, C. P. (2014). Meaningful work: Connecting business ethics and organization studies. Journal of Business Ethics, 121, 77-90. DOI: $10.1007 / \mathrm{s} 10551-013-1675-5$

Mueller, J. S., Melwani, S., \& Goncalo, J. A. (2012). The bias against creativity: Why people desire but reject creative ideas. Psychological Science, 23, 13-17. https://doi.org/10.1177/0956797611421018

Muthén, L. K., \& Muthén, B. O. (2012). Mplus Version 7 user's guide. Los Angeles, CA: Muthén \& Muthén.

Oldham, G. R. (2003). Stimulating and supporting creativity in organizations. In S. E. Jackson, M. A. Hitt \& A.S. DeNisi (Eds.), Managing knowledge for sustained competitive advantage: Designing strategies for effective human resource management (pp. 243-273). San Francisco: Jossey-Bass.

O'Neill, T. A., McLarnon, M. J., Xiu, L., \& Law, S. J. (2016). Core self-evaluations, perceptions of group potency, and job performance: The moderating role of individualism and collectivism cultural profiles. Journal of Occupational and Organizational Psychology, 89, 447-473. DOI: 10.1111/joop.12135

Park, N. K., Chun, M. Y., \& Lee, J. (2016). Revisiting individual creativity assessment: Triangulation in subjective and objective assessment methods. Creativity Research Journal, 28, 1-10. https://doi.org/10.1080/10400419.2016.1125259

Perry-Smith, J. E., \& Shalley, C. E. (2003). The social side of creativity: A static and dynamic 


\section{RUNNING HEAD: CSE AND CREATIVITY}

social network perspective. Academy of Management Review, 28, 89-106. DOI: $10.5465 / A M R .2003 .8925236$

Podsakoff, P. M., MacKenzie, S. B., Lee, J. Y., \& Podsakoff, N. P. (2003). Common method biases in behavioral research: a critical review of the literature and recommended remedies. Journal of Applied Psychology, 88, 879-903. http://dx.doi.org/10.1037/0021-9010.88.5.879

Podsakoff, P. M., MacKenzie, S. B., \& Podsakoff, N. P. (2012). Sources of method bias in social science research and recommendations on how to control it. Annual Review of Psychology, 63, 539-569. https://doi.org/10.1146/annurev-psych-120710-100452

Pratt, M. G., \& Ashforth, B. E. (2003). Fostering meaningfulness in working and at work. In K. S. Cameron, J. E. Dutton, \& R. E. Quinn (Eds.), Positive organizational scholarship (pp. 309-327). San Francisco: Berrett-Koehler Publishers, Inc.

Preacher, K. J., \& Hayes, A. F. (2008). Asymptotic and resampling strategies for assessing and comparing indirect effects in multiple mediator models. Behavior Research Methods, 40, 879-891. DOI: 10.3758/BRM.40.3.879

Preacher, K. J., Rucker, D. D., \& Hayes, A. F. (2007). Addressing moderated mediation hypotheses: Theory, methods, and prescriptions. Multivariate Behavioral Research, 42, 185-227. https://doi.org/10.1080/00273170701341316

Radaelli, G., Lettieri, E., Mura, M., \& Spiller, N. (2014). Knowledge sharing and innovative work behaviour in healthcare: A micro-level investigation of direct and indirect effects. Creativity and Innovation Management, 23, 400-414. https://doi.org/10.1111/caim.12084

Reagan R, \& McEvily B. (2003). Network structure and knowledge transfer: The effects of cohesion and range. Administrative Science Quarterly, 48, 240-267. https://doi.org/10.2307/3556658 
RUNNING HEAD: CSE AND CREATIVITY

Rich, B. L., Lepine, J. A., \& Crawford, E. R. (2010). Job engagement: Antecedents and effects on job performance. Academy of Management Journal, 53, 617-635. https://doi.org/10.5465/amj.2010.51468988

Rode, J. C., Judge, T. A., \& Sun, J. M. (2012). Incremental validity of core self-evaluations in the presence of other self-concept traits: An investigation of applied psychology criteria in the United States and China. Journal of Leadership \& Organizational Studies, 19, 326-340. https://doi.org/10.1177/1548051812442964

Rosso, B. D., Dekas, K. H., \& Wrzesniewski, A. (2010). On the meaning of work: A theoretical integration and review. Research in Organizational Behavior, 30, 91-127. $\underline{\text { https://doi.org/10.1016/j.riob.2010.09.001 }}$

Shah, N. P., Cross, R., \& Levin, D. Z. (2018). Performance benefits from providing assistance in networks relationships that generate learning. Journal of Management. 44, 412444. https://doi.org/10.1177/0149206315584822

Spector, P. E. (2006). Method variance in organizational research: truth or urban legend?. Organizational Research Methods, 9, 221-232. https://doi.org/10.1177/1094428105284955

Steger, M. F., \& Dik, B. J. (2010). Work as meaning: Individual and organizational benefits of engaging in work meaningfulness. In P. A. Linley, S. Harrington, \& N. Page (Eds.), Oxford handbook of positive psychology and work (pp.131-142). Oxford, England: Oxford University Press.

Steger, M. F., Dik, B. J., \& Duffy, R. D. (2012). Measuring work meaningfulness: The work and meaning inventory (WAMI). Journal of Career Assessment, 20, 322-337. https://doi.org/10.1177/1069072711436160

Steger, M. F., Littman-Ovadia, H., Miller, M., Menger, L., \& Rothmann, S. (2013). Engaging in work even when it is meaningless: Positive affective disposition and work 


\section{RUNNING HEAD: CSE AND CREATIVITY}

meaningfulness interact in relation to work engagement. Journal of Career Assessment, 21, 348-361. https://doi.org/10.1177/1069072712471517

Tierney, P., \& Farmer, S. M. (2002). Creative self-efficacy: Its potential antecedents and relationships to creative performance. Academy of Management Journal, 45, 11371148. https://doi.org/10.5465/3069429

Umphress, E. E., Bingham, J. B., \& Mitchell, M. S. (2010). Unethical behavior in the name of the company: The moderating effect of organizational identification and positive reciprocity beliefs on unethical pro-organizational behavior. Journal of Applied Psychology, 95, 769-780. http://dx.doi.org/10.1037/a0019214

Wanberg, C. R., Glomb, T. M., Song, Z., \& Sorenson, S. (2005). Job-search persistence during unemployment: A 10-wave longitudinal study. Journal of Applied Psychology, 90, 411-430. http://dx.doi.org/10.1037/0021-9010.90.3.411

Wang, S., \& Noe, R. A. (2010). Knowledge sharing: A review and directions for future research. Human Resource Management Review, 20, 115-131. https://doi.org/10.1016/j.hrmr.2009.10.001

Williams, L. J., Vandenberg, R. J., \& Edwards, J. R. (2009). 12 structural equation modeling in management research: a guide for improved analysis. Academy of Management Annals, 3, 543-604. https://doi.org/10.5465/19416520903065683

Wrzesniewski, A., McCauley, C., Rozin, P., \& Schwartz, B. (1997). Jobs, careers, and callings: People's relations to their work. Journal of Research in Personality, 31, 21 33. https://doi.org/10.1006/jrpe.1997.2162

Zhang, H., Kwan, H. K., Zhang, X., \& Wu, L. Z. (2014). High core self-evaluators maintain creativity: A motivational model of abusive supervision. Journal of Management, 40, 1151-1174. https://doi.org/10.1177/0149206312460681

Zhou, J., \& George, J. M. (2001). When job dissatisfaction leads to creativity: Encouraging 


\section{RUNNING HEAD: CSE AND CREATIVITY}

the expression of voice. Academy of Management Journal, 44, 682-696.

https://doi.org/10.5465/3069410 
TABLE 1

Confirmatory Factor Analyses Results

\begin{tabular}{|c|c|c|c|c|c|c|c|c|}
\hline Model & $\chi^{2}$ & $d f$ & $\Delta \chi^{2}$ & $\triangle d f$ & CFI & TLI & SRMR & RMSEA \\
\hline Model 1: Four factors & $64.94 * *$ & 38 & & & .99 & .98 & .03 & .06 \\
\hline Model 2: Three factors & $134.04 * *$ & 41 & $69.10 * *$ & 3 & .95 & .93 & .06 & .11 \\
\hline Model 3: Two factors & $366.01 * *$ & 43 & $301.07 * *$ & 5 & .83 & .78 & .09 & .19 \\
\hline Model 4: One factor & $850.14^{* *}$ & 44 & $785.20 * *$ & 6 & .57 & .46 & .20 & .30 \\
\hline
\end{tabular}

Notes: $\mathrm{N}=200$. Model 1: Baseline model with core self-evaluation (CSE), work meaningfulness, knowledge sharing and creativity loaded on their intended factors; Model 2: Three-factor model with CSE and work meaningfulness loaded onto one factor. This is the best alternative

model among all models we tested. Model 3: Two-factor model with CSE, work meaningfulness and knowledge sharing loaded onto one factor; Model 4: One-factor model with all items loaded onto one factor. 
TABLE 2

Means, SDs, Correlations and Reliabilities

\begin{tabular}{|c|c|c|c|c|c|c|c|c|c|c|}
\hline & Mean & $\mathrm{SD}$ & 1 & 2 & 3 & 4 & 5 & 6 & 7 & 8 \\
\hline 1. Gender ${ }^{\mathrm{a}}$ (T1E) & .70 & .46 & $(-)$ & & & & & & & \\
\hline 2. $\operatorname{Age}^{\mathrm{b}}(\mathrm{T} 1 \mathrm{E})$ & 1.48 & .58 & -.11 & $(-)$ & & & & & & \\
\hline 3. Marital status ${ }^{\mathrm{c}}$ (T1E) & .47 & .50 & -.12 & $.56^{* *}$ & $(-)$ & & & & & \\
\hline 4. Education $^{\mathrm{d}}(\mathrm{T} 1 \mathrm{E})$ & 2.28 & .75 & .13 & $.14^{*}$ & .01 & $(-)$ & & & & \\
\hline 5. $\mathrm{CSE}(\mathrm{T} 1 \mathrm{E})$ & 3.59 & .60 & $.14^{*}$ & $-.16^{*}$ & -.09 & -.01 & $(.86)$ & & & \\
\hline 6. Knowledge sharing (T1E) & 4.64 & .77 & .08 & -.12 & -.07 & .11 & $.53^{* *}$ & $(.89)$ & & \\
\hline 7. Creativity (T2S) & 3.98 & .86 & $.15^{*}$ & -.03 & -.11 & $.21^{*}$ & $.26^{* *}$ & $.29^{* *}$ & $(.89)$ & \\
\hline 8. Work meaningfulness (T1E) & 4.65 & .95 & .02 & -.07 & -.05 & -.02 & $.67^{* *}$ & $.54^{* *}$ & $.20^{* *}$ & $(.95)$ \\
\hline
\end{tabular}

Note: $\mathrm{N}=200 ; \mathrm{CSE}=$ Core Self-evaluation. Where relevant, Cronbach's coefficient alphas are given on the diagonal in parentheses. T1E $=$ rated by employee at Time 1; T2S=rated by supervisor at Time 2 .
a. $0=$ female, $1=$ male;
b. $1=30$ years and below, $2=31$ to 40 years; $3=41$ years and above;
c. $1=$ married, $2=$ unmarried;
d. $1=$ bachelor degree; $2=$ master degree; $3=$ doctoral degree.
${ }^{*} p<05$

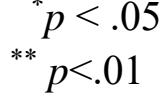


TABLE 3

Results of the Moderated Mediation Models

\begin{tabular}{lcc}
\hline & & Indirect effect \\
\hline CSE $\rightarrow$ Knowledge Sharing $\rightarrow$ Creativity & Estimate & Bias-corrected 95\% CI \\
High work meaningfulness & & \\
Low work meaningfulness & $\mathbf{. 0 8}$ & {$[.02, . \mathbf{1 9}]$} \\
Difference between low and high & .04 & {$[-.01, .14]$} \\
\end{tabular}

Note. $\mathrm{CI}=$ confidence interval; Bootstrap samples $=5,000$; The numbers in bold indicate significant estimates. CSE $=$ Core Self-Evaluation. 
FIGURE 1

Hypothesized Model

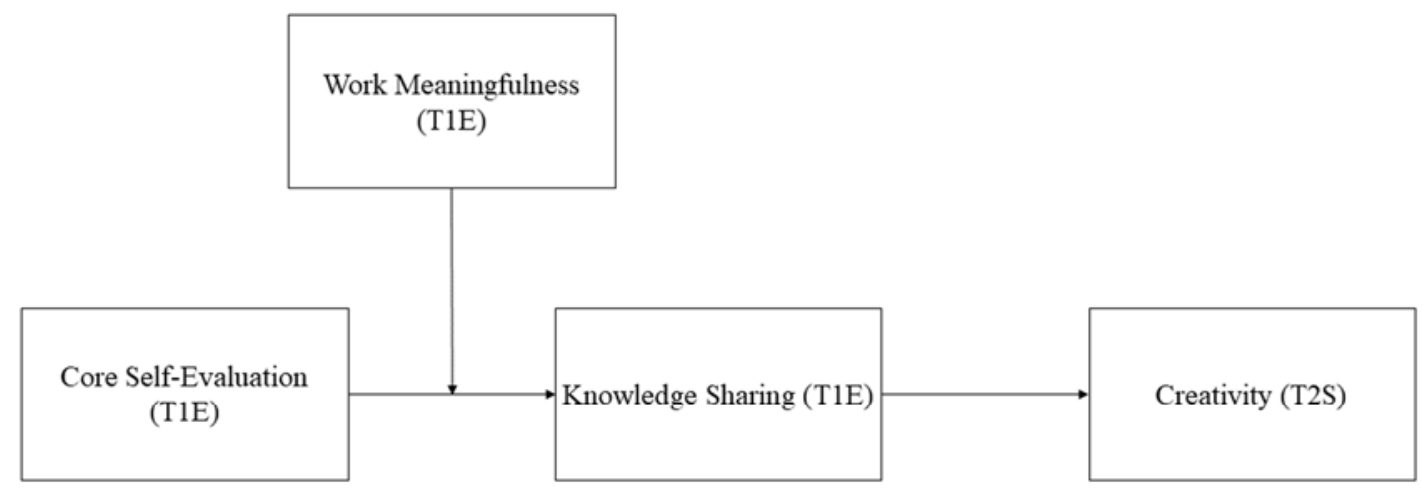

Note. $\mathrm{T} 1 \mathrm{E}=$ rated by employee at Time $1 ; \mathrm{T} 2 \mathrm{~S}=$ rated by supervisor at Time 2. 
FIGURE 2

Structural Equation Modeling Results of the Moderated Mediation Model

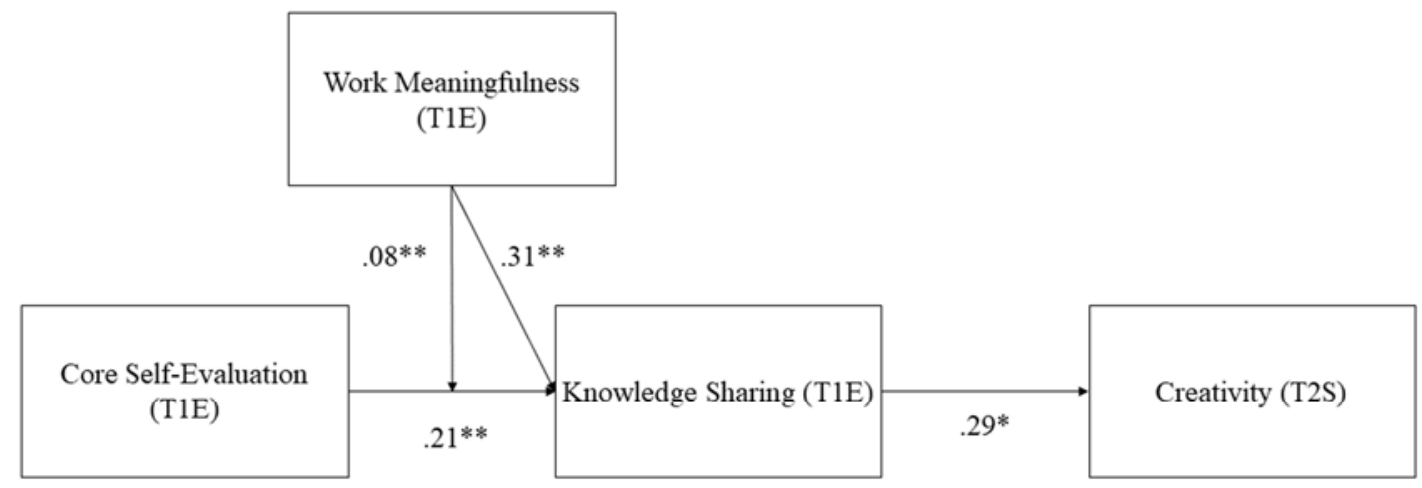

Note. $\mathrm{T} 1 \mathrm{E}=$ rated by employee at Time $1 ; \mathrm{T} 2 \mathrm{~S}=$ rated by supervisor at Time 2 .

Model fit indices: $\chi^{2}[14]=30.458, p<.01, \mathrm{CFI}=.974, \mathrm{TLI}=.953, \mathrm{RMSEA}=.077, \mathrm{SRMR}=.031$. ${ }^{*} p<.05$

${ }^{* * *} p<.01$ 
FIGURE 3

Moderating Effect of Work Meaningfulness on the Relationship between CSE and Knowledge Sharing

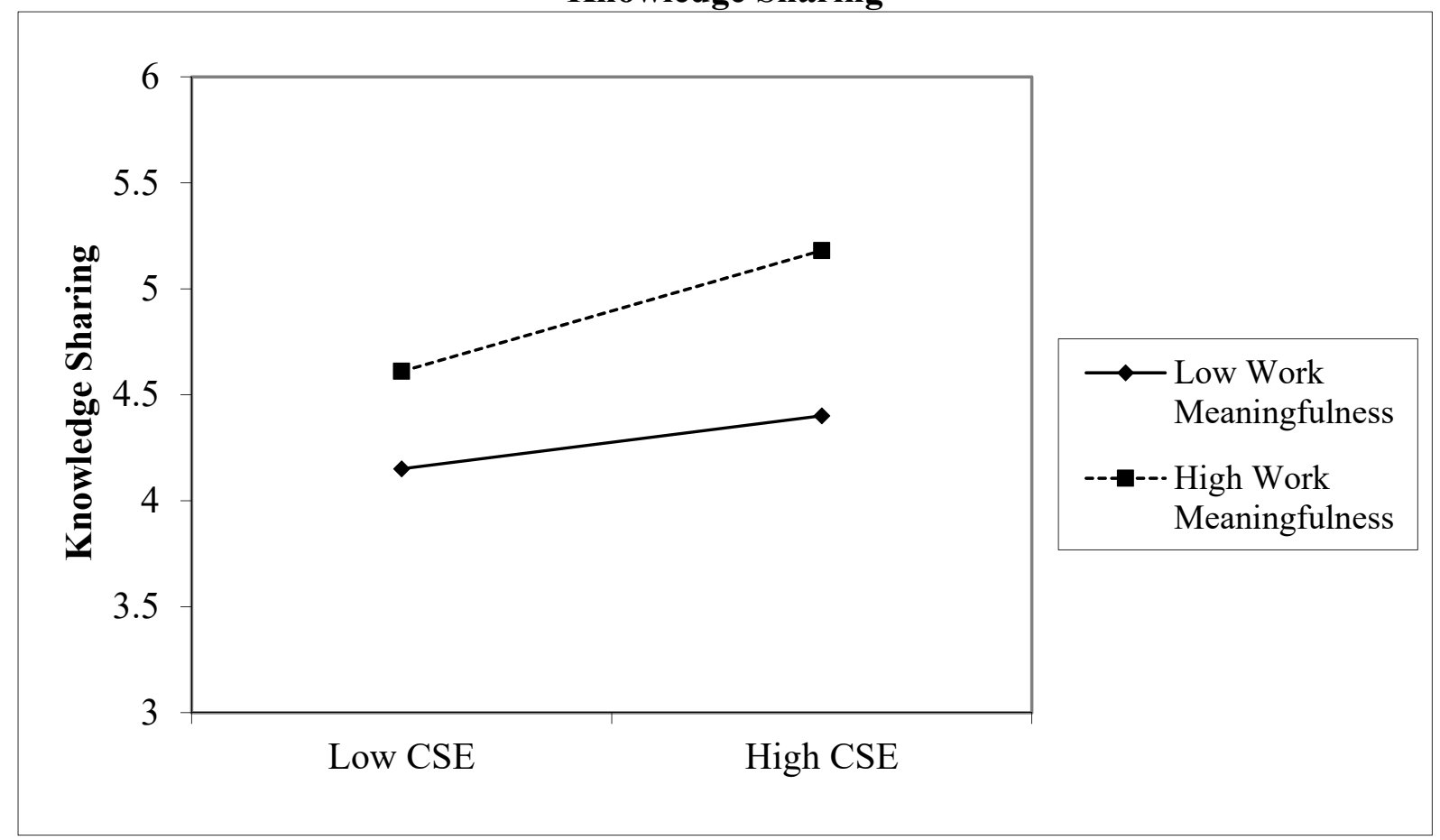

Note: CSE=Core Self-Evaluation. 